\title{
Article
}

\section{Poor-Prognosis Patients Affected by Glioblastoma: Retrospective Study of Hypofractionated Radiotherapy with Simultaneous Integrated Boost and Concurrent/Adjuvant Temozolomide}

\author{
Fabiana Gregucci ${ }^{1}$, Alessia Surgo ${ }^{1}$ (D), Ilaria Bonaparte ${ }^{1}$, Letizia Laera ${ }^{2}$, Maria Paola Ciliberti ${ }^{1}$, \\ Roberta Carbonara ${ }^{1}$, Maria Annunziata Gentile ${ }^{3}$, David Giraldi ${ }^{4}$, Roberto Calbi ${ }^{3}$, Morena Caliandro ${ }^{1}$, \\ Nicola Sasso ${ }^{2}$, Salvatore D’Oria ${ }^{4}$, Carlo Somma ${ }^{4}$, Gaetano Martinelli ${ }^{3}$, Giammarco Surico ${ }^{2}$, \\ Giuseppe Lombardi ${ }^{5}$ id and Alba Fiorentino ${ }^{1, * \mathbb{C}}$
}

Citation: Gregucci, F.; Surgo, A.; Bonaparte, I.; Laera, L.; Ciliberti, M.P. Carbonara, R.; Gentile, M.A.; Giraldi, D.; Calbi, R.; Caliandro, M.; et al. Poor-Prognosis Patients Affected by Glioblastoma: Retrospective Study of Hypofractionated Radiotherapy with Simultaneous Integrated Boost and Concurrent/Adjuvant Temozolomide. J. Pers. Med. 2021, 11, 1145. https://doi.org/10.3390/ jpm11111145

Academic Editors: Roberto Pallini and Quintino Giorgio D'Alessandris

Received: 6 September 2021

Accepted: 30 October 2021

Published: 4 November 2021

Publisher's Note: MDPI stays neutral with regard to jurisdictional claims in published maps and institutional affiliations.

Copyright: (C) 2021 by the authors Licensee MDPI, Basel, Switzerland. This article is an open access article distributed under the terms and conditions of the Creative Commons Attribution (CC BY) license (https:// creativecommons.org/licenses/by/ $4.0 /)$.
1 Department of Radiation Oncology, Miulli General Regional Hospital,

70021 Acquaviva delle Fonti, Bari, Italy; fabianagregucci@gmail.com (F.G.); surgo.alessia@gmail.com (A.S.); ilariabonaparte@libero.it (I.B.); m.ciliberti@miulli.it (M.P.C.); roberta.carbonara@yahoo.it (R.C.); morenacaliandro@yahoo.it (M.C.)

2 Department of Medical Oncology, Miulli General Regional Hospital, 70021 Acquaviva delle Fonti, Bari, Italy; 1.laera@miulli.it (L.L.); n.sasso@miulli.it (N.S.); giammarco.surico@miulli.it (G.S.)

3 Department of Radiology, Miulli General Regional Hospital, 70021 Acquaviva delle Fonti, Bari, Italy; m.gentile@miulli.it (M.A.G.); r.calbi@miuli.it (R.C.); g.martinelli@miulli.it (G.M.)

4 Department of Neurosurgery, Miulli General Regional Hospital, 70021 Acquaviva delle Fonti, Bari, Italy; d.giraldi@miulli.it (D.G.); s.doria@miulli.it (S.D.); c.somma@miulli.it (C.S.)

5 Department of Oncology, Oncology 1, Veneto Institute of Oncology IOV-IRCCS, 35128 Padua, Padova, Italy; giuseppe.lombardi@iov.veneto.it

* Correspondence: a.fiorentino@miulli.it; Tel.: +39-0803054608

Abstract: Background: Glioblastoma (GBM) is a very poor-prognosis brain tumor. To date, maximal excision followed by radiochemotherapy, in 30 fractions, is the standard approach. Limited data are present in the literature about hypofractionated radiotherapy (hypo-RT) in GBM poor prognosis patients. Thus, this retrospective study was conducted to evaluate efficacy and toxicity of hypo-RT with simultaneous integrated boost (SIB) in association with temozolomide (TMZ) in this patient setting. Methods: Poor-prognosis GBM patients underwent surgery (complete, subtotal or biopsy) followed by SIB-hypo-RT and concomitant/adjuvant TMZ. The prescription dose was 40.05 Gy (15 fractions) with a SIB of 52.5 Gy (3.5 Gy/fraction) on surgical cavity/residual/macroscopic disease. Volumetric modulated arc therapy was performed. Results: From July 2019 to July 2021, 30 poor-prognosis patients affected by GBM were treated by SIB-hypo-RT; 25 were evaluated in the present analysis due to a minimum follow up of 6 months. The median age and KPS were 65 years and $60 \%$, respectively. At the median follow-up time of 15 months (range 7-24), median and 1-year overall survival and progression-free survival were 13 months and 54\%, and 8.4 months and $23 \%$, respectively. No acute or late neurological side effects of grade $\geq 2$ were reported. Grade 3-4 hematologic toxicity occurred in three cases. Conclusion: SIB-hypo-RT associated with TMZ in poor-prognosis patients affected by GBM is an effective and safe treatment. Prospective studies could be warranted.

Keywords: glioblastoma; poor prognosis; radiotherapy; chemotherapy

\section{Introduction}

Glioblastoma (GBM) is the most common and devastating malignancy of the brain with a median survival time of 12-18 months [1]. Maximal safe resection, when feasible, is the first effective treatment, followed by adjuvant radiotherapy (RT) and chemotherapy 
with temozolomide [1]. Radical debulking, tumor size, performance status and the patient's age are related to overall survival (OS) [1].

The first data supporting the use of adjuvant RT, alone or in association with bischloroethyl nitrosourea (BCNU), to increase OS and progression free survival (PFS) were reported more than 40 years ago [2]. In 2005, the introduction of concurrent and adjuvant temozolomide (TMZ) with RT (60 Gy in 30 fractions), adopted by the European Organization for Research and Treatment of Cancer (EORTC) and the National Cancer Institute of Canada (NCIC) in a Phase III randomized trial, showed an improvement in terms of oncological outcome. In fact, the 2-year OS and PFS rates were $27 \%$ and $10.7 \%$, respectively [1]. Considering the high incidence of local recurrence in GBM, generally within $2 \mathrm{~cm}$ from the original edges of the tumors, and the patients' death due to local progression, the goal of the treatment approach should be the improvement of local control [3-5]. Therefore, postoperative RT modalities, including total dose and new fractionation schedules, have been evaluated for these patients [3-5].

The technological improvement in RT, including the introduction of intensity modulated radiotherapy (IMRT/VMAT) and image-guided radiotherapy (IGRT), with more precise target coverage sparing the surrounding healthy tissue, has led to hypofractionated (hypo-RT) schemes [6,7]. In fact, several hypo-RT studies in high-grade gliomas have reported good results in terms of efficacy and toxicity [8-13]. Malmstrom et al. [12] in 2012 published a randomized Phase III trial with three comparison arms: TMZ alone vs. standard RT (60 Gy in 30 fractions) vs. hypo-RT (34 Gy in 10 fractions) in patients older than 60 years. The authors concluded that in elderly patients over 70 years, both TMZ and hypo-RT should be considered as standard treatment options. The multicentric Phase II study published by Scoccianti et al. [13] evaluated the OS, PFS and toxicity of a hypo-RT with simultaneous integrated boost (SIB) in association with TMZ in patients with relatively good prognosis (RPA Classes III-IV). All patients received 52.5 Gy in 15 fractions and, concomitantly, 67.5 Gy to the SIB volume. Despite low accrual, the authors concluded that hypo-RT is a reasonable and feasible option for GBM patients [13].

Few data are present in literature about hypo-RT and poor-prognosis patients. Moreover, the definition of poor-prognosis GBM has not been defined, due to the different pathological and clinical features. In the setting of poor-prognosis patients, no standard of care is available, suggesting that RT alone, TMZ alone or best supportive care could be proposed. However, in this setting, several results were correlated only with elderly and frail people, for whom the reduction of RT fractions could represent a valid option with a median OS of 6-8 months [11,14-27].

For poor-prognosis patients other than those with advanced age and frailty, the data are sparse.

Based on this background and the lack of specific data in this setting, aim of the present retrospective study was to assess the toxicity profile and outcome in poor-prognosis patients affected by GBM treated with hypo-RT with SIB and concomitant/adjuvant TMZ. Moreover, a literature review on the management of elderly and/or frail patients affected by high-grade gliomas treated with hypo-RT was conducted.

\section{Materials and Methods}

Inclusion criteria were as follows: newly diagnosed with histologically proven GBM; poor-prognosis patients; more than 18 years of age; Karnofsky performance scale (KPS) more than 50; all patients belonged to recursive partitioning analysis (RPA) [28] Classes IV, V and VI (IV: age $<50$ years, KPS $<90$; age $\geq 50$ years, KPS $\geq 70$, total or subtotal resection, good neurological function; V: age $\geq 50$ years, KPS $<70$, stereotactic biopsy, GBM, neurological function that inhibits the ability to work; VI: age $\geq 50$ years, KPS $<70$, abnormal mental status); patient's refusal to receive 30 fractions; and adequate bone marrow, renal and liver function. All patients underwent debulking surgery; in the case of tumor unresectability, a biopsy procedure was performed in order to obtain the tumor diagnosis. Subtotal resection was defined as less than $100 \%$ and more than $50 \%$ of the 
tumor. The exclusion criteria were prior brain radiotherapy, brainstem tumors, age below 18 years; KPS below 50. Informed consent was obtained from all patients included in the study.

The definition of poor prognostic factors other than advanced age included KPS or RPA class, neurological symptoms after surgical procedures or symptoms of mass effect, high tumor burden, unresectable or multifocal lesions, high comorbidity and potential low treatment compliance due to rapidly progressive disease.

The end points of the study were the evaluation of PFS, OS, acute and late toxicity.

Patients were immobilized in the supine position with a thermoplastic open mask (Solstice $^{\text {TM }}$ SRS Immobilization System, CIVCO $^{\circledR}$ Radiotherapy). Computed tomography (CT) simulation was performed without contrast, acquiring slices of $1 \mathrm{~mm}$ thickness. Coregistration with post-surgery magnetic resonance imaging (MRI) was mandatory. Organs at risk (OARs) were contoured: brain (normal brain minus planning target volume (PTV)), eyes, lens, optic chiasm, optic nerves, brainstem and spinal cord, and hippocampus. The gross tumor volume (GTV) was defined on the T1 with gadolinium-weighted MRI, and it included the surgical cavity with or without any residual contrast-enhanced lesion or the entire lesion, if only a biopsy was performed. The clinical target volume for the SIB (CTV1) was defined as the GTV without the margin, whereas the clinical target volume for the lower-dose volume (CTV2) was obtained by adding a 10-15 mm margin to the CTV1, respecting the anatomical barriers and OARs. The PTV1 and PTV2 were created by a CTV expansion of 2-3 mm. The total dose was 52.5 Gy for PTV1 and 40.05 Gy for PTV2 in 15 fractions. An example is shown in Figure 1.

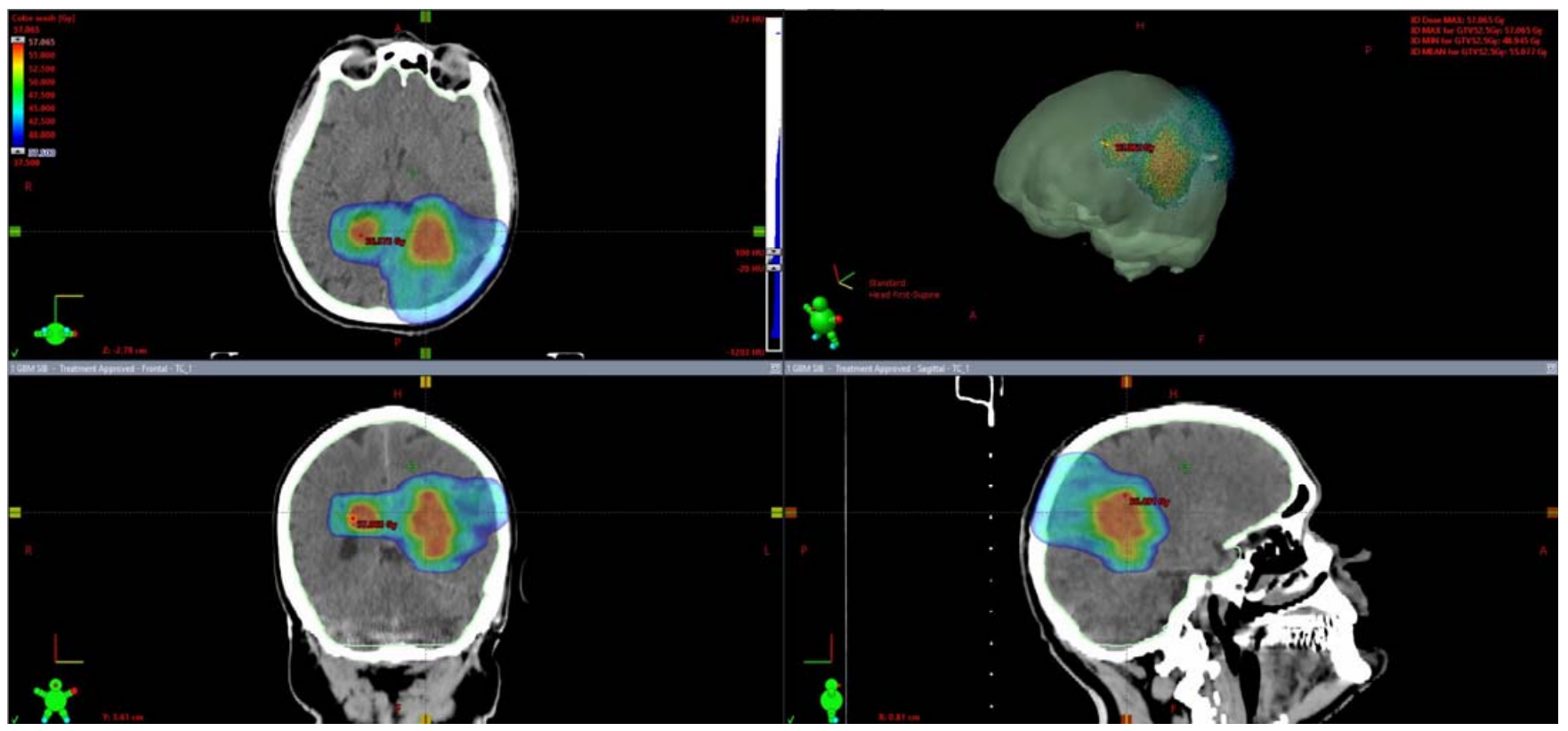

Figure 1. Example of a volumetric arc therapy treatment plan with simultaneous integrated boost.

For RT planning, $6 \times$ flattening filter free $(\mathrm{FFF})$ and volumetric modulated arc therapy (VMAT) plans were generated with two or more coplanar or non-coplanar partial arcs by TrueBeam $^{\mathrm{TM}}$ (Varian Medical System). All treatment plans were optimized for PTV so that more than $98 \%$ of the PTV received at least $95 \%$ of the prescribed dose. The prescribed PTV1 dose of 52.5 Gy in 3 weeks corresponded to a biological effective dose (BED) similar to standard RT (BED 10 of 70.88 Gy versus 72 Gy, respectively) [13,17].

During RT, IGRT with cone-beam CT (CBCT) and real-time surface-guided RT, using AlignRT $^{\circledR}$, was performed daily prior to and during the RT session. Concomitant TMZ at a dose of $75 \mathrm{mg}$ per square meter of body-surface area per day for 21 consecutive days, 7 days/week, was administered from Day 1 until the final day of hypo-RT [1]. Blood 
count was monitored weekly throughout the treatment. During hypo-RT, patients received $2-4 \mathrm{mg} /$ day of dexamethasone with a proton pump inhibitor. If feasible, patients underwent $6-12$ cycles or until progression of adjuvant TMZ (150-200 mg/mq/day, 5 days every 28 days) 4 weeks from the end of RT [1]. During treatment, antiepileptic and antiemetic drugs were administered when necessary.

Clinical evaluations and MRI were performed 45-60 days after the end of the hypo-RT, then every 2-3 months for the first 2 years or as appropriate. At each visit, neurological status and the severity of complications were rated according to the National Cancer Institute Common Toxicity Criteria (NCI-CTC Version 4). Adverse neurological events were considered to be consequences of treatment in the absence of disease progression. The RANO response criteria were adopted to evaluate the disease status [29].

The outcome variables were acute and late toxicity, PFS and OS. The acute and late toxicity were considered as categorial variables, defined according to the NCI-CTC scale. Moreover, the presence/absence of radio-necrosis was recorded as a dichotomous variable. The PFS was calculated from the date of RT to the time of progression or the last followup date. The OS was calculated from the date of RT to death for any cause or the last follow-up date. The Kaplan-Meier method was used to evaluate PFS and OS. A log-rank test was used to compare the different subgroups in univariate analysis. Multivariate analysis was performed to determine the independent prognostic factors by using the Cox regression model. A two-sided $p$-value equal to or less than 0.05 was considered statistically significant. The following prognostic factors were evaluated: sex, age ( $<65 \mathrm{vs.} \geq 65)$, KPS ( $\leq 60$ vs. $>60$ ), RPA (IV vs. V + VI), CCI ( $<8$ vs. $\geq 8$ ), mass effect (yes vs. not), multifocal tumor (yes vs. no), surgery (surgery vs. biopsy), resection (complete vs. incomplete), O6methylguanin-DNA-methyltransferase (MGMT) promoter methylation status (methylated vs. not methylated), GTV ( $\leq 50$ vs. $>50)$ and PTV ( $\leq 200$ vs. $>200)$. Data management and statistical analysis were conducted using the open-source R platform (version 3.5.2).

\section{Results}

From July 2019 to July 2021, 30 poor-prognosis patients affected by GBM underwent hypo-RT with SIB. Of these, 25 cases were evaluated in the present analysis because they had a minimum follow up of 6 months.

Table 1 reports the clinical characteristics of the study population. The median age, KPS and Charlson comorbidity index (CCI) were 65 years (range 37-82), 60\% (range 50-90\%) and 8 (range 5-14), respectively. Eighteen patients (72\%) had RPA Class $\geq$ V. All patients were affected by wild-type GBM isocitrate dehydrogenase (IDH) 1 ; in $76 \%$ of cases, MGMT was unmethylated. Subtotal resection was performed in 22 patients (88\%), including 10 cases (40\%) of unresectable disease in which biopsy alone was performed. At diagnosis, 15 patients $(60 \%)$ showed signs or symptoms of mass effect and required anti-edema therapy. The median time between the surgical procedure and RT was 8 weeks (range 2-14).

Table 1. Patients and tumor characteristics.

\begin{tabular}{cccc}
\hline Number of Patients & & 25 & \\
\hline Sex & Male & 18 & $(72 \%)$ \\
\hline & Female & 7 & $(28 \%)$ \\
\hline Age & & \\
\hline & Median (range) in years & 65 & $(37-82)$ \\
\hline$<60$ years & 5 & $(20 \%)$ \\
\hline $60-65$ years & 11 & $(44 \%)$ \\
\hline & $>65$ years & 9 & $(36 \%)$ \\
\hline
\end{tabular}


Table 1. Cont.

\begin{tabular}{|c|c|c|c|}
\hline Number of Patients & & 25 & \\
\hline \multicolumn{4}{|l|}{ KPS Score } \\
\hline & Median (range), in \% & 60 & $(50-90)$ \\
\hline & $<60 \%$ & 5 & $(20 \%)$ \\
\hline & $60-70 \%$ & 16 & $(64 \%)$ \\
\hline & $>70 \%$ & 4 & $(16 \%)$ \\
\hline \multicolumn{4}{|l|}{ RPA Class } \\
\hline & Median (range) & $\mathrm{V}$ & (IV-VI) \\
\hline & IV & 7 & $(28 \%)$ \\
\hline & $\mathrm{V}$ & 10 & $(40 \%)$ \\
\hline & VI & 8 & $(32 \%)$ \\
\hline \multicolumn{4}{|l|}{ CCI } \\
\hline & Median (range) & 8 & $(5-14)$ \\
\hline & $<7$ & 6 & $(24 \%)$ \\
\hline & $7-9$ & 18 & $(72 \%)$ \\
\hline & $>9$ & 2 & $(4 \%)$ \\
\hline \multicolumn{4}{|l|}{ Mass Effect } \\
\hline & Yes & 15 & $(60 \%)$ \\
\hline & No & 10 & $(40 \%)$ \\
\hline \multicolumn{4}{|l|}{ Surgery } \\
\hline & Complete & 3 & $(12 \%)$ \\
\hline & Incomplete & 12 & $(48 \%)$ \\
\hline & Unresectable (biopsy) & 10 & $(40 \%)$ \\
\hline \multicolumn{4}{|l|}{ Multifocal Tumor } \\
\hline & Yes & 7 & $(28 \%)$ \\
\hline & No & 18 & $(72 \%)$ \\
\hline \multicolumn{4}{|l|}{ Poor Molecular Factors } \\
\hline & wild-type IDH & 25 & $(100 \%)$ \\
\hline & Unmethylated MGMT & 19 & $(76 \%)$ \\
\hline \multicolumn{4}{|l|}{ Gross Tumor Volume } \\
\hline & Median (range), in cc & 50 & $(31-135)$ \\
\hline & $\leq 50 \mathrm{cc}$ & 16 & $(64 \%)$ \\
\hline & $>50 \mathrm{cc}$ & 9 & $(36 \%)$ \\
\hline \multicolumn{4}{|l|}{ Planning Target Volume } \\
\hline & Median (range), in cc & 220 & $(117-358)$ \\
\hline & $\leq 200 \mathrm{cc}$ & 12 & $(48 \%)$ \\
\hline & $>200 \mathrm{cc}$ & 13 & $(52 \%)$ \\
\hline
\end{tabular}

Compliance with SIB hypo-RT with TMZ was $100 \%$.

Adjuvant TMZ was administered to $20(80 \%)$ patients (six cycles median, range 3-15), while five patients were not eligible due to their clinical condition and progression of the disease. 
At the 15 month median follow-up, 14 patients (56\%) were alive: three $(12 \%)$ showed a partial treatment response, three $(12 \%)$ had a stable disease and eight $(32 \%)$ showed progression of the disease. The median OS was 13 months (95\% CI 9.8-na) and 1-year OS was 54\% (95\% CI 31-73\%); the median PFS was 8.4 months (95\% CI 5.8-11.9) and the 1-year PFS was 23\% (95\% CI 7-44\%). The OS and PFS Kaplan-Meyer survival curves are shown in Figure 2.
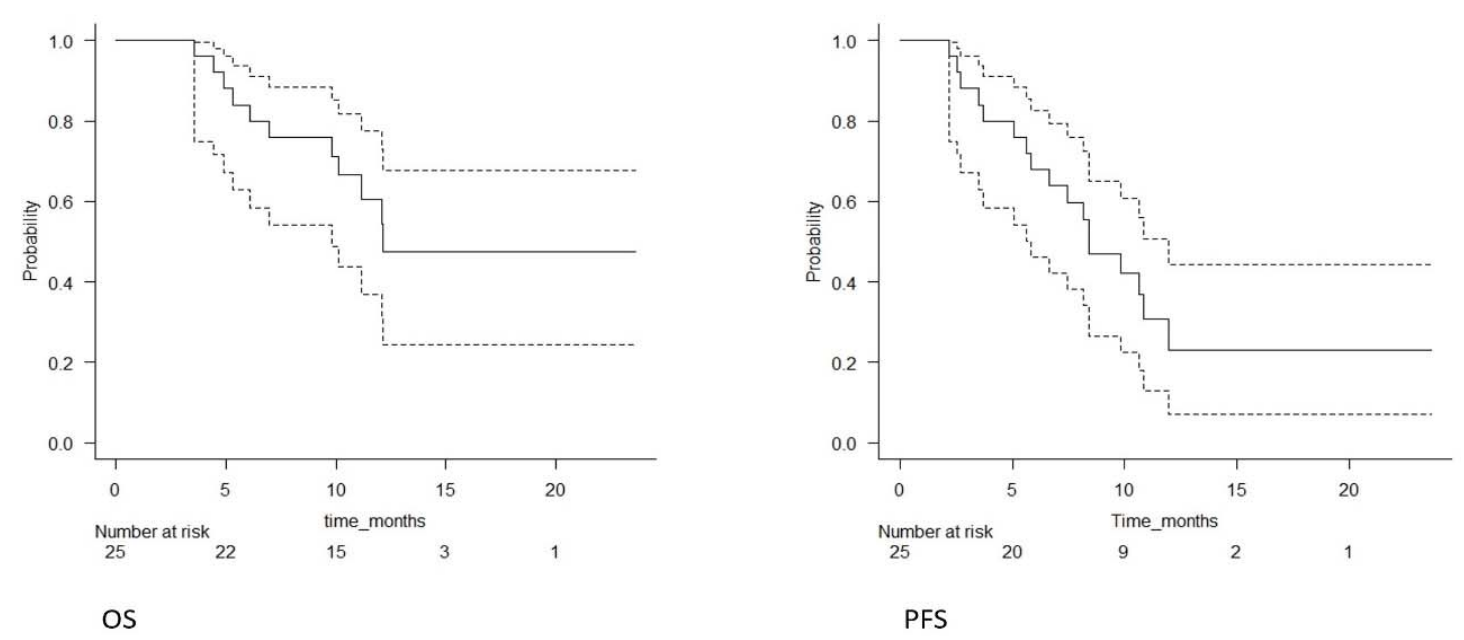

Figure 2. Overall survival and progression-free survival of the entire population (solid lines); confidence intervals (dotted lines).

Regarding toxicity, no acute or late neurological side effects of more than Grade 2 were reported, without cases of radio-necrosis. Grade 3-4 hematologic toxicity occurred in three cases.

Neurocognitive assessments pre- and post-hypo-RT were available in a limited number of patients $(15 \%)$ and are therefore unreliable.

Of the 17 cases of disease progression, eight received re-irradiation followed by secondline systemic therapy (regorafenib or fotemustine), three received regorafenib alone and six were evaluated for best supportive care.

\section{Prognostic Factors for OS and PFS}

The univariate and multivariate prognostic factors influencing OS are shown in Table 2. Seven significant variables in the univariate analysis (age, RPA, multifocal tumor, resection, MGMT status, GTV and PTV) were entered into the multivariable model. As a result, MGMT non-methylation (HR: 0.61, 95\% CI: 0.02-13.66, $p=0.05$ ), GTV > 50 cc (HR: 4.83, 95\% CI: 0.83-27.88, $p=0.01$ ) and PTV > 200 cc (HR:2.14, 95\% CI: 0.01-9.87, $p=0.02)$ were significant negative prognostic factors for survival. The univariate and multivariate prognostic factors influencing PFS are shown in Table 3. Six significant variables in the univariate analysis (mass effect, multifocal tumor, surgery, resection, MGMT status and PTV) were entered into the multivariable model. As a result, multifocal tumor (HR: 1.76, 95\% CI: $0.31-8.12, p=0.05$ ), incomplete resection (HR: 2.91, 95\% CI: 0.31-27.07, $p=0.01$ ), MGMT unmethylation (HR: 0.79, 95\% CI: 0.11-6.25, $p=0.03$ ) and PTV > $200 \mathrm{cc}$ (HR: 1.99, 95\% CI: $0.26-5.37, p=0.05$ ) were significant negative prognostic factors for disease progression.

Table 2. Univariate and multivariate analysis of prognostic factors for overall survival.

\begin{tabular}{|c|c|c|c|c|c|c|}
\hline Variable & Univariate & & & ltivar & & \\
\hline & HR & $95 \% \mathrm{CI}$ & $p$ & HR & $95 \%$ CI & $p$ \\
\hline Sex & 1.23 & $0.3-2.3$ & 0.7 & - & - & - \\
\hline Age ( $\geq 65$ years) & 1.622 & $0.48-5.38$ & 0.04 & 2.88 & $0.72-11.43$ & 0.1 \\
\hline
\end{tabular}


Table 2. Cont.

\begin{tabular}{|c|c|c|c|c|c|c|}
\hline Variable & Univariate & & & lltivar & & \\
\hline KPS $(\leq 60 \%)$ & 0.42 & $0.05-3.32$ & 0.4 & - & - & - \\
\hline $\mathrm{RPA}(\geq \mathrm{V})$ & 1.78 & $0.37-8.38$ & 0.04 & 0.19 & $0.01-2.78$ & 0.2 \\
\hline $\mathrm{CCI}(\geq 8)$ & 1.201 & $0.34-4.17$ & 0.7 & - & - & - \\
\hline Mass effect (yes) & 1.51 & $0.39-5.81$ & 0.5 & - & - & - \\
\hline Multifocal tumor (yes) & 1.92 & $0.56-6.61$ & 0.02 & 2.95 & $0.51-16.98$ & 0.2 \\
\hline Surgery (yes) & 0.82 & $0.24-2.73$ & 0.7 & - & - & - \\
\hline Resection (incomplete) & 2.29 & $0.04-6.43$ & 0.01 & 0.96 & $0.16-5.78$ & 0.9 \\
\hline MGMT methylation (absent) & 0.25 & $0.03-2.02$ & 0.04 & 0.61 & $0.02-13.66$ & 0.05 \\
\hline GTV $(>50 \mathrm{cc})$ & 5.208 & $1.37-19.71$ & 0.01 & 4.83 & $0.83-27.88$ & 0.01 \\
\hline PTV $(>200$ cc) & 0.29 & $0.08-1.06$ & 0.06 & 2.14 & $0.01-9.87$ & 0.02 \\
\hline
\end{tabular}

Table 3. Univariate and multivariate analysis of prognostic factors for progression-free survival.

\begin{tabular}{|c|c|c|c|c|c|c|}
\hline \multirow[t]{2}{*}{ Variable } & \multirow{2}{*}{$\begin{array}{c}\text { Univariate } \\
\text { HR }\end{array}$} & \multicolumn{5}{|c|}{ Multivariate } \\
\hline & & $95 \% \mathrm{CI}$ & $p$ & HR & $95 \% \mathrm{CI}$ & $p$ \\
\hline Sex & 0.81 & $0.27-2.39$ & 0.7 & - & - & - \\
\hline Age ( $\geq 65$ years) & 0.77 & $0.28-2.14$ & 0.6 & - & - & - \\
\hline $\mathrm{KPS}(\leq 60 \%)$ & 0.89 & $0.25-3.17$ & 0.8 & - & - & - \\
\hline $\mathrm{RPA}(\geq \mathrm{V})$ & 0.83 & $0.28-2.48$ & 0.7 & - & - & - \\
\hline $\mathrm{CCI}(\geq 8)$ & 0.95 & $0.35-2.54$ & 0.9 & - & - & - \\
\hline Mass effect (yes) & 1.47 & $0.05-4.23$ & 0.04 & 1.32 & $0.29-5.97$ & 0.7 \\
\hline Multifocal tumor (yes) & 1.38 & $0.04-6.72$ & 0.04 & 1.76 & $0.31-8.12$ & 0.05 \\
\hline Surgery (yes) & 1.76 & $0.02-3.04$ & 0.05 & 1.32 & $0.18-3.27$ & 0.7 \\
\hline Resection (incomplete) & 2.96 & $0.3-22.42$ & 0.02 & 2.91 & $0.31-27.07$ & 0.01 \\
\hline MGMT methylation (absent) & 1.99 & $0.04-4.06$ & 0.06 & 0.79 & $0.11-6.25$ & 0.03 \\
\hline GTV $(>50 \mathrm{cc})$ & 0.82 & $0.31-2.24$ & 0.7 & - & - & - \\
\hline PTV $(>200 \mathrm{cc})$ & 1.95 & $0.04-3.74$ & 0.06 & 1.99 & $0.26-5.37$ & 0.05 \\
\hline
\end{tabular}

\section{Discussion}

To our knowledge, there are limited data regarding the role of hypo-RT plus TMN in poor-prognosis GBM patients, other than advanced age.

Older age, clinical performance status and RPA class are the most relevant prognostic factors; due to the rapid progression of the disease, up to $10 \%$ of these patients discontinue or do not start treatment $[17,18]$. Based on this later consideration, the possibility of reducing the overall radiotherapy treatment time without detrimental effects on the outcomes, represent the real challenge for this subgroup of patients.

In 1994, Bauman et al. showed that a palliative RT course of $30 \mathrm{~Gy}$ in 10 fractions could be useful in terms of survival in elderly GBM patients with a low pretreatment KPS $(<50)$ [27]. A Phase III trial conducted by Roa and colleagues compared two different hypofractionation schemes (40 Gy in 15 fractions and 25 Gy in five fractions) without concurrent TMZ in patients over 65 years of age with KPS > 50 [11]. However, the optimal dose in this subpopulation remained unclear. No differences in OS, PFS or quality of life were observed between the two arms. However, this study has been criticized for its low statistical relevance and the presence of other bias (differences in the patients' characteristics, trial design and treatment delivery). On the other hand, the Nordic Clinical 
Brain Tumor Study reported poorer OS outcomes in elderly GBM patients treated with standard RT (60 Gy in 30 fractions) in comparison with those who received hypo-RT (34 Gy in 10 fractions) [12]. Pedretti et al. published a randomized trial in which 14 poor-prognosis patients were enrolled to received hypo-RT ( $30 \mathrm{~Gy}$ in six fractions) and 17 received TMZ exclusively (TMZ $200 \mathrm{mg} / \mathrm{m}^{2} /$ day for 5 days every 28 days). RPA VI $(p=0.048)$ and the absence of MGMT methylation ( $p=0.001)$ worsened OS significantly. Biopsy $(p=0.048)$, RPA Class VI $(p=0.04)$ and TMZ ( $p=0.007)$ worsened PFS. Despite the limited accrual, the authors concluded that RT had a better PFS, without significant differences in OS [24].

However, despite the limitations highlighted, short-course RT and standard RT were equivalent in terms of outcome and safety [7-27]. These results led to an increased use of hypo-RT schemes in frail and elderly GBM patients.

However, few data have been produced for GBM patients with poor prognostic factors such as high tumor burden, unresectable or multifocal lesions, low Karnofsky performance status (KPS) or the presence of significant comorbidities [15,17].

For this reason, the present analysis reported data regarding the use of hypo-RT with concomitant and adjuvant TMZ in GBM patients with poor prognosis factors other than age. The present population, in fact, had a median age of 65 years, all patients had a high comorbidity score; $40 \%$ of the patients received only a biopsy, around $30 \%$ of patients had multifocal disease, more than $50 \%$ of patients had a high disease burden (PTV more than 200 cc), 80\% had unmethylated MGMT and 72\% of cases were in RPA Class V-VI.

This analysis is the first report about the use of a concomitant boost for poor-prognosis GBM patients, showing the safety and the efficacy of the approach. As shown in Table 4, overall survival in this patient setting ranged from 5 to 9 months. Thus, the present results are interesting, due to the median OS and PFS of 13 and 8 months.

Regarding poor prognosis, our analysis could be compared with two published papers, due to the similar hypo-RT schedule and enrolled population [15,17].

The Phase II trial published by Navarria et al. showed the feasibility and effectiveness of a hypo-RT schedule with adjuvant TMZ in 30 poor-prognosis GBM patients [17]. The authors prescribed a total dose of $52.5 \mathrm{~Gy}$ in 3 weeks. The aim of the study was to improve the median OS from 6 to 12 months, but this was not achieved; moreover, $10 \%$ of the patients did not complete the planned hypo-RT. The median PFS and 12-month PFS rates were 5 months and $20.0 \%$, while median and 12-month OS rates of 8 months and $30 \%$, respectively, were achieved [17]. Ten percent of patients experienced acute or late neurologic toxicity.

Jablonska et al. proposed hypo-RT (40 Gy in 15 fraction) with concurrent TMZ in 17 GBM patients with poor prognostic factors (elderly age, post-surgical neurological complications, high tumor burden, unresectable or multifocal lesions) [15]. The authors showed excellent compliance, with a low toxicity profile and a PFS of $60 \%$ at 6 months, $33 \%$ at 1 year and $13 \%$ at 2 years; while the median OS time was 7 months; the 6-month, 1-, and 2-year OS rates were $62 \%, 46 \%$, and $18 \%$, respectively [15].

Regarding the hypo-RT schedule, the present study is the first one reporting a SIBhypo-RT schedule for poor-prognosis patients: $40 \mathrm{~Gy}$ in 15 fractions for PTV (similar to Jablonska et al.'s study [15]) and 52.5 Gy simultaneously to residual mass (similar to Navarria's trial [17]). Based on the present schedule, all patients completed the planned treatment and, probably due to the boost dose to residual mass, the median PFS was high (8.4 months). Our data reported a low toxicity rate and a high median survival compared with the other reports (7 vs. 8 vs. 13 months), probably due to the SIB dose and second-line therapy at recurrence. In fact, among 17 recurrences, eight patients received a second irradiation with or without second-line chemotherapy such as regorafenib [30-32]. 
Table 4. Literature review of studies regarding elderly/frail patients with high-grade gliomas and treated with hypofractionated RT.

\begin{tabular}{|c|c|c|c|c|c|c|c|c|c|}
\hline $\begin{array}{c}\text { Author/Publication } \\
\text { Year }\end{array}$ & Study Years & Study Type & Patient Selection & Comparison & $\begin{array}{c}\text { No. of } \\
\text { Patients }\end{array}$ & RT Schedule & Median PFS & Median OS & Toxicities \\
\hline $\begin{array}{l}\text { Phillips et al. } \\
2003 \text { [9] }\end{array}$ & 1990-1996 & $\begin{array}{l}\text { Randomized } \\
\text { Phase III }\end{array}$ & $\begin{array}{l}\text { Age }>45 \text { y } \\
\text { ECOG 0-3 }\end{array}$ & $\begin{array}{l}\text { Hypo-RT } \\
\text { Standard RT }\end{array}$ & $\begin{array}{l}32 \\
36\end{array}$ & $\begin{array}{c}35 \mathrm{~Gy} / 10 \mathrm{fx}(\mathrm{WB}) \\
60 \mathrm{~Gy} / 30 \mathrm{fx}\end{array}$ & NS & $\begin{array}{l}8.7 \text { months } \\
10.3 \text { months }\end{array}$ & None \\
\hline $\begin{array}{l}\text { Roa et al. } \\
2004 \text { [11] }\end{array}$ & 1996-2001 & $\begin{array}{l}\text { Randomized } \\
\text { Phase III }\end{array}$ & $\begin{array}{c}\text { Age } \geq 60 y \\
\text { KPS } \geq 50\end{array}$ & $\begin{array}{c}\text { Hypo-RT } \\
\text { Standard RT }\end{array}$ & $\begin{array}{l}48 \\
47 \\
\end{array}$ & $\begin{array}{l}40 \mathrm{~Gy} / 15 \mathrm{fx} \\
60 \mathrm{~Gy} / 30 \mathrm{fx}\end{array}$ & NS & $\begin{array}{l}5.6 \text { months } \\
5.1 \text { months }\end{array}$ & NS \\
\hline $\begin{array}{l}\text { Malmström et al. } \\
2012[12]\end{array}$ & 2000-2009 & $\begin{array}{l}\text { Randomized } \\
\text { Phase III }\end{array}$ & Age $\geq 60$ y ECOG 0-2 & $\begin{array}{c}\text { TMZ } \\
\text { Hypo-RT } \\
\text { Standard RT }\end{array}$ & $\begin{array}{c}93 \\
98 \\
100 \\
\end{array}$ & $\begin{array}{c}\text { NA } \\
34 \mathrm{~Gy} / 10 \mathrm{fx} \\
60 \mathrm{~Gy} / 30 \mathrm{fx}\end{array}$ & NS & $\begin{array}{c}8.3 \text { months } \\
7.5 \text { months } \\
6 \text { months }\end{array}$ & No $G>3$ acute toxicity \\
\hline $\begin{array}{l}\text { Roa et al. } \\
2015 \text { [18] }\end{array}$ & 2010-2013 & $\begin{array}{l}\text { Randomized } \\
\text { Phase III }\end{array}$ & $\begin{array}{l}\text { Age } \geq 65 y \\
\text { KPS } 50-70\end{array}$ & $\begin{array}{l}\text { Hypo-RT } \\
\text { Hypo-RT }\end{array}$ & $\begin{array}{l}48 \\
50\end{array}$ & $\begin{array}{l}25 \mathrm{~Gy} / 5 \mathrm{fx} \\
40 \mathrm{~Gy} / 15 \mathrm{fx}\end{array}$ & $\begin{array}{l}4.2 \text { months } \\
4.2 \text { months }\end{array}$ & $\begin{array}{l}7.9 \text { months } \\
6.4 \text { months }\end{array}$ & No $G>3$ acute toxicity \\
\hline $\begin{array}{l}\text { Guedes de Castro et al. } \\
2017 \text { [19] }\end{array}$ & NS & $\begin{array}{l}\text { Randomized } \\
\text { Phase III }\end{array}$ & $\begin{array}{l}\text { Age } \geq 65 \text { y } \\
\text { KPS 50-70 }\end{array}$ & $\begin{array}{l}\text { Hypo-RT } \\
\text { Hypo-RT }\end{array}$ & $\begin{array}{l}26 \\
35 \\
\end{array}$ & $\begin{array}{l}25 \mathrm{~Gy} / 5 \mathrm{fx} \\
40 \mathrm{~Gy} / 15 \mathrm{fx}\end{array}$ & $\begin{array}{l}4.3 \text { months } \\
3.2 \text { months }\end{array}$ & $\begin{array}{l}6.8 \text { months } \\
6.2 \text { months }\end{array}$ & No $G>3$ acute toxicity \\
\hline $\begin{array}{l}\text { Perry et al. } \\
2017 \text { [16] }\end{array}$ & 2007-2013 & $\begin{array}{l}\text { Randomized } \\
\text { Phase III }\end{array}$ & Age $\geq 65$ y ECOG $0-2$ & $\begin{array}{c}\text { Hypo-RT + TMZ } \\
\text { Нypo-RT }\end{array}$ & $\begin{array}{l}281 \\
281\end{array}$ & $40 \mathrm{~Gy} / 15 \mathrm{fx}$ & $\begin{array}{l}5.3 \text { months } \\
3.9 \text { months }\end{array}$ & $\begin{array}{l}9.3 \text { months } \\
7.6 \text { months }\end{array}$ & No $G>3$ acute toxicity \\
\hline $\begin{array}{l}\text { Pedretti et al. } \\
2019 \text { [24] }\end{array}$ & 2010-2015 & $\begin{array}{l}\text { Randomized } \\
\text { Phase II }\end{array}$ & RPA Class 5 or 6 & $\begin{array}{l}\text { Hypo-RT alone } \\
\text { TMZ alone }\end{array}$ & $\begin{array}{l}14 \\
17\end{array}$ & $30 \mathrm{~Gy} / 6 \mathrm{fx}$ over 2 weeks & 3.8 months & 6.3 months & No $G>3$ acute toxicity \\
\hline $\begin{array}{l}\text { Bauman et al. } \\
\quad 1994[27]\end{array}$ & 1990-1992 & Prospective & $\begin{array}{l}\text { Age } \geq 65 \text { y } \\
\text { KPS } \leq 50\end{array}$ & Hypo-RT & 29 & 30 Gy /10 fx (WB) & NS & 6 months & NS \\
\hline $\begin{array}{l}\text { Thomas et al. } \\
1994 \text { [29] }\end{array}$ & 1991-1993 & Prospective & $\begin{array}{l}\text { KPS } \leq 50 \text { or } \\
\text { Age } 55-70 \text { y } \\
\text { KPS } 50-70 \text { or } \\
\text { Age } \geq 70 \text { y }\end{array}$ & Hypo-RT & 38 & 30 Gy / 6 fx over 2 weeks & NS & 6 months & None \\
\hline $\begin{array}{l}\text { Hulshof et al. } \\
2000[19]\end{array}$ & 1988-1998 & Prospective & Age $\geq 65$ y MRC $\geq 2$ & $\begin{array}{c}\text { Hypo-RT } \\
\text { Hypo-RT } \\
\text { Standard RT }\end{array}$ & $\begin{array}{l}48 \\
41 \\
66\end{array}$ & $\begin{array}{l}28 \mathrm{~Gy} / 4 \mathrm{fx} \\
40 \mathrm{~Gy} / 8 \mathrm{fx} \\
66 \mathrm{~Gy} / 33 \mathrm{fx}\end{array}$ & NS & $\begin{array}{l}6.6 \text { months } \\
5.6 \text { months } \\
7 \text { months }\end{array}$ & $\begin{array}{l}\text { Mild; } \\
\text { No difference between } \\
\text { groups }\end{array}$ \\
\hline $\begin{array}{l}\text { Minniti et al. } \\
2009 \text { [21] }\end{array}$ & 2002-2006 & Prospective & $\begin{array}{l}\text { Age } \geq 70 y \\
\text { KPS } \geq 60\end{array}$ & $\begin{array}{l}\text { Hypo-RT + } \\
\text { adj TMZ }\end{array}$ & 43 & 30 Gy / 6 fx over 2 weeks & 6.3 months & 9.3 months & $\begin{array}{c}8 \text { patients presented } \\
\text { neurological deterioration (Grade } \\
2 / 3 \text { confusion } \\
\text { and/or somnolence). } \\
12 \text { patients had Grade } 3 / 4 \\
\text { hematological toxic effects }\end{array}$ \\
\hline
\end{tabular}


Table 4. Cont.

\begin{tabular}{|c|c|c|c|c|c|c|c|c|c|}
\hline $\begin{array}{c}\text { Author/Publication } \\
\text { Year } \\
\end{array}$ & Study Years & Study Type & Patient Selection & Comparison & $\begin{array}{c}\text { No. of } \\
\text { Patients }\end{array}$ & RT Schedule & Median PFS & Median OS & Toxicities \\
\hline $\begin{array}{l}\text { Omuro et al. } \\
2014 \text { [26] }\end{array}$ & NS & Prospective & $\begin{array}{c}\text { Age } \geq 18 \text { years } \\
\text { (median } 55 \text { y) } \\
\text { KPS } \geq 70 \\
\text { (median } 90) \\
\text { Partial resection or } \\
\text { biopsy }(75 \%)\end{array}$ & Hypo-RT + TMZ + BEV & 40 & 30 Gy/ 6 fx over 2 weeks & 10 months & 19 months & None \\
\hline $\begin{array}{c}\text { Navarria et al. } \\
2019 \text { [17] }\end{array}$ & 2013-2016 & Prospective & $\begin{array}{c}\text { Age } \geq 70 \text { y } \\
\text { KPS } \leq 60\end{array}$ & Нypo-RT & 30 & $52.5 \mathrm{~Gy} / 15 \mathrm{fx}$ & 5 months & 8 months & $\begin{array}{l}\text { No severe acute or late } \\
\text { neurologic toxicity } \\
\text { was recorded }\end{array}$ \\
\hline $\begin{array}{l}\text { McAleese et al. } \\
\quad 2003[8]\end{array}$ & 1991-1999 & Retrospective & $\begin{array}{l}\text { KPS } \leq 50 \text { or } \\
\text { Age 50-70 y } \\
\text { KPS 50-90 or } \\
\text { Age } \geq 70 \text { y }\end{array}$ & Hypo-RT & 92 & 30 Gy $/ 6$ fx over 2 weeks & NS & 5 months & NS \\
\hline $\begin{array}{l}\text { Chang et al. } \\
2003 \text { [10] }\end{array}$ & 1988-2001 & Retrospective & RPA Class $\geq 4$ & Hypo-RT & 59 & $50 \mathrm{~Gy} / 20 \mathrm{fx}$ & 3.9 months & 7 months & 3 patients showed radio-necrosis \\
\hline $\begin{array}{l}\text { Minniti el al. } \\
2015 \text { [23] }\end{array}$ & 2004-2013 & Retrospective & $\begin{array}{l}\text { Age } \geq 65 \text { y } \\
\text { KPS } \geq 60\end{array}$ & $\begin{array}{c}\text { Hypo-RT + TMZ } \\
\text { Standard RT + TMZ }\end{array}$ & $\begin{array}{l}116 \\
127\end{array}$ & $\begin{array}{c}40 \mathrm{~Gy} / 15 \mathrm{fx} \\
59.4-60 \mathrm{~Gy} / 30-33 \mathrm{fx}\end{array}$ & $\begin{array}{l}6.7 \text { months } \\
5.6 \text { months }\end{array}$ & $\begin{array}{l}12.5 \text { months } \\
12 \text { months }\end{array}$ & $\begin{array}{l}28 \text { patients receiving standard } \\
\text { RT and } 11 \text { subjected to short-course } \\
\text { RT had acute worsening of } \\
\text { neurologic status. } \\
20 \text { patients receiving standard RT } \\
\text { and } 3 \text { patients receiving short-course } \\
\text { RT had late neurologic deterioration } \\
\text { (G2-3 cognitive disability) } \\
\text { G3-4 thrombocytopenia and } \\
\text { lymphocytopenia were seen in } \\
24 \text { patients and } 51 \text { patients. G3 } \\
\text { neutropenia developed in } 14 \text { patients, } \\
\text { and } 10 \text { patients displayed G3 anemia }\end{array}$ \\
\hline $\begin{array}{c}\text { Jablonska et al. } \\
2019 \text { [15] }\end{array}$ & 2010-2017 & Retrospective & RPA Class $\geq 4$ & Hypo-RT with SIB + TMZ & 17 & $50-45-40$ Gy/15 fx & 7 months & 7 months & $\begin{array}{l}\text { No acute G3-5 toxicities } \\
\text { were observed. } \\
\text { Radio-necrosis occurred in } 1 \text { patient. }\end{array}$ \\
\hline Present study & 2019-2021 & Retrospective & $\begin{array}{l}\text { Poor prognosis } \\
\text { RPA Class } \geq 4\end{array}$ & Hypo-RT with SIB + TMZ & 25 & $52.5-40 \mathrm{~Gy} / 15 \mathrm{fx}$ & 8.4 months & 13 months & $\begin{array}{l}\text { No acute or late neurological side } \\
\text { effects of grade } \geq 2 \text { were reported. } \\
\text { No cases of radio-necrosis. Grade } \\
3-4 \text { hematologic toxicity occurred in } \\
3 \text { cases. }\end{array}$ \\
\hline
\end{tabular}

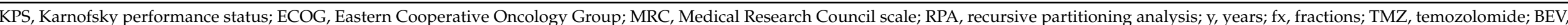

bevacizumab; WB, whole brain; SIB, simultaneous integrated boost; NA, not applicable; NS, not specified. 
The most important limitations of the present analysis are the poor sample size and the retrospective nature of the study. However, in GBM patients with poor prognostic factors other than age, the two studies published in the literature by Navarria and Jablonska enrolled 30 and 17 patients, respectively, due to the difficulty of enrolling this type of patients. In fact, in real-world data, patients with primary GBM, poor performance status $(\mathrm{KPS}<60)$ and age $>70$, multifocal disease, high comorbidities correlated with a high risk of mortality [33-35] and other negative prognostic factors are candidates for TMZ or best supportive care (BSC).

Moreover, due to the latter motivation, it will be difficult to collect strong data in terms of prospective or randomized trials for this population.

\section{Conclusions}

The present results suggest that the use of SIB hypo-RT (52.5/40 Gy in 15 fractions) with concurrent and adjuvant TMZ could also be contemplated in poor-prognosis GBM patients. However, a direct comparison among BSC, TMZ alone and hypo-RT is required in order to evaluate the best strategy to improve the outcome and quality of life.

Author Contributions: Conceptualization, F.G. and A.F.; data curation, A.S., I.B., L.L., M.P.C., R.C. (Roberta Carbonara), M.A.G., M.C., N.S., S.D., C.S., G.M., G.S. and A.F.; formal analysis, F.G.; methodology, F.G., M.A.G., R.C. (Roberto Calbi), G.L. and A.F.; software, I.B.; supervision, I.B., L.L., D.G., R.C. (Roberto Calbi), G.S., G.L. and A.F.; writing-original draft, F.G. and A.F.; writing-review and editing, A.S., M.P.C., R.C. (Roberta Carbonara), D.G., M.C., N.S., S.D., C.S., G.M., G.S. and A.F. All authors have read and agreed to the published version of the manuscript.

Funding: This research received no external funding.

Institutional Review Board Statement: The study was conducted according to the guidelines of the Declaration of Helsinki, and approved by the Institutional Review Board of General Regional Hospital F. Miulli (protocol code RT-pGBM-2019).

Informed Consent Statement: Written informed consent has been obtained from the patient(s) to publish this paper.

Data Availability Statement: The data are available upon request from the corresponding author.

Acknowledgments: All radiotherapy staff: Gianluca Ladisa, Luciana Branà, Annarita Ciocia, Domenico Curci, Alberto Aga, Francesco Berloco, Marina Demasi, Federica Fragnoli, Rosilda Cuscito, Giuseppe Sanfrancesco, Christian Depascali, Chiara Indellicati, Rosalinda Parabita, Daniela Nardelli, Maria Nardiello, Valeria De Candia.

Conflicts of Interest: The authors declare no conflict of interest.

\section{References}

1. Stupp, R.; Mason, W.; Van der Bent, M.; Weller, M.; Fisher, B.; Taphoorn, M.J.; Belanger, K.; Brandes, A.A.; Marosi, C.; Bogdahn, U.; et al. European Organisation for Research and Treatment of Cancer Brain Tumor and Radiotherapy Groups, National Cancer Institute of Canada Clinical Trials Group. Radiotherapy plus concomitant and adjuvant Temozolomide for glioblatoma. N. Engl. J. Med. 2005, 352, 987-996. [CrossRef] [PubMed]

2. Walker, M.D.; Strike, T.A. An evaluation of methyl-CCNU, BCNU and radiotherapy in the treatment of malignant glioma. Proc. Am. Assoc. Cancer Res. 1976, 17, 63.

3. Balducci, M.; Apicella, G.; Manfrida, S.; Mangiola, A.; Fiorentino, A.; Azario, L.; D’Agostino, G.R.; Frascino, V.; Dinapoli, N.; Mantini, G.; et al. Single- Arm Phase II Study of Conformal Radiation Therapy and Temozolomide plus fractionated Stereotactic Conformal Boost in High grade Gliomas. Strahlentherapie und Onkologie 2010, 186, 558-564. [CrossRef] [PubMed]

4. Balducci, M.; Chiesa, S.; Diletto, B.; D’Agostino, G.R.; Mangiola, A.; Manfrida, S.; Mantini, G.; Albanese, A.; Fiorentino, A.; Frascino, V.; et al. Low-dose fractionated radiotherapy and concomitant chemotherapy in glioblastoma multiforme with poor prognosis: A feasibility study. Neuro Oncol. 2012, 14, 79-86. [CrossRef]

5. Lee, S.W.; Fraass, B.A.; Marsh, L.H.; Herbort, K.; Gebarski, S.S.; Martel, M.K.; Radany, E.H.; Lichter, A.S.; Sandler, H.M. Patterns of failure following high-dose 3-D conformal radiotherapy for high-grade astrocytomas: A quantitative dosimetric study. Int. J. Radiat. Oncol. Biol. Phys. 1999, 43, 79-88. [CrossRef]

6. Mazzola, R.; Corradini, S.; Gregucci, F.; Figlia, V.; Fiorentino, A.; Alongi, F. Role of Radiosurgery/Stereotactic Radiotherapy in Oligometastatic Disease: Brain Oligometastases. Front. Oncol. 2019, 9, 206. [CrossRef] [PubMed] 
7. Mazzola, R.; Corradini, S.; Gregucci, F.; Figlia, V.; Fiorentino, A.; Alongi, F. Volume de-escalation in radiation therapy: State of the art and new perspectives. J. Cancer Res. Clin. Oncol. 2020, 146, 909-924.

8. McAleese, J.J.; Stenning, S.P.; Ashley, S.; Traish, D.; Hines, F.; Sardell, S.; Guerrero, D.; Brada, M. Hypofractionated radiotherapy for poor prognosis malignant glioma: Matched pair survival analysis with MRC controls. Radiother. Oncol. 2003, 67, 177-182. [CrossRef]

9. Phillips, C.; Guiney, M.; Smith, J.; Hughes, P.; Narayan, K.; Quong, G. A randomized trial comparing 35 Gy in ten fractions with $60 \mathrm{~Gy}$ in 30 fractions of cerebral irradiation for glioblastoma multiforme and older patients with anaplastic astrocytoma. Radiother. Oncol. 2003, 68, 23-26. [CrossRef]

10. Chang, E.L.; Yi, W.; Allen, P.K.; Levin, V.A.; Sawaya, R.E.; Maor, M.H. Hypofractionated radiotherapy for elderly or younger low performance status glioblastoma patients: Outcome and prognostic factors. Int. J. Radiat. Oncol. Biol. Phys. 2003, 56, 519-528. [CrossRef]

11. Roa, W.; Brasher, P.M.A.; Bauman, G.; Anthes, M.; Bruera, E.; Chan, A.; Fisher, B.; Fulton, D.; Gulavita, S.; Hao, C.; et al. Abbreviated course of radiation therapy in older patients with glioblastoma multiforme: A prospective randomized clinical trial. J. Clin. Oncol. 2004, 22, 1583-1588. [CrossRef] [PubMed]

12. Malmström, A.; Grønberg, B.H.; Marosi, C.; Stupp, R.; Frappaz, D.; Schultz, H.; Abacioglu, U.; Tavelin, B.; Lhermitte, B.; Hegi, M.E.; et al. Temozolomide versus standard 6-week radiotherapy versus hypofractionated radiotherapy in patients older than 60 years with glioblastoma: The Nordic randomised, phase 3 trial. Lancet Oncol. 2012, 13, 916-926. [CrossRef]

13. Scoccianti, S.; Krengli, M.; Marrazzo, L.; Magrini, S.M.; Detti, B.; Fusco, V.; Pirtoli, L.; Doino, D.; Fiorentino, A.; Masini, L.; et al. Hypofractionated radiotherapy with simultaneous integrated boost (SIB) plus temozolomide in good prognosis patients with glioblastoma: A multicenter phase II study by the Brain Study Group of the Italian Association of Radiation Oncology (AIRO). Radiol. Med. 2018, 123, 48-62. [CrossRef]

14. Wick, W.; Platten, M.; Meisner, C.; Felsberg, J.; Tabatabai, G.; Simon, M.; Nikkhah, G.; Papsdorf, K.; Steinbach, J.P.; Sabel, M.; et al. Temozolomide chemotherapy alone versus radiotherapy alone for malignant astrocytoma in the elderly: The NOA-08 randomised, phase 3 trial. Lancet Oncol. 2012, 13, 707-715. [CrossRef]

15. Jablonska, P.A.; Diez-Valle, R.; Pérez-Larraya, J.G.; Moreno-Jiménez, M.; Idoate, M.Á.; Arbea, L.; Tejada, S.; Garcia de Eulate, M.R.; Ramos, L.; Arbizu, J.; et al. Hypofractionated radiation therapy and temozolomide in patients with glioblastoma and poor prognostic factors. A prospective, single-institution experience. PLoS ONE 2019, 14, e0217881.

16. Perry, J.R.; Laperriere, N.; O'Callaghan, C.J.; Brandes, A.A.; Menten, J.; Phillips, C.; Fay, M.; Nishikawa, R.; Cairncross, J.G.; Roa, W.; et al. Trial Investigators. Short-Course Radiation plus Temozolomide in Elderly Patients with Glioblastoma. N. Engl. J. Med. 2017, 376, 1027-1037. [CrossRef]

17. Navarria, P.; Pessina, F.; Cozzi, L.; Tomatis, S.; Reggiori, G.; Simonelli, M.; Santoro, A.; Clerici, E.; Franzese, C.; Carta, G.; et al. Phase II study of hypofractionated radiation therapy in elderly patients with newly diagnosed glioblastoma with poor prognosis. Tumori 2019, 105, 47-54. [CrossRef]

18. Roa, W.; Kepka, L.; Kumar, N.; Sinaika, V.; Matiello, J.; Lomidze, D.; Hentati, D.; Guedes de Castro, D.; Dyttus-Cebulok, K.; Drodge, S.; et al. International Atomic Energy Agency Randomized Phase III Study of Radiation Therapy in Elderly and/or Frail Patients With Newly Diagnosed Glioblastoma Multiforme. J. Clin. Oncol. 2015, 33, 4145-4150. [CrossRef] [PubMed]

19. de Castro, D.G.; Matiello, J.; Roa, W.; Ghosh, S.; Kepka, L.; Kumar, N.; Sinaika, V.; Lomidze, D.; Hentati, D.; Rosenblatt, E.; et al. Survival Outcomes With Short-Course Radiation Therapy in Elderly Patients With Glioblastoma: Data From a Randomized Phase 3 Trial. Int. J. Radiat. Oncol. Biol. Phys. 2017, 98, 931-938. [CrossRef]

20. Hulshof, M.C.; Schimmel, E.C.; Bosch, D.A.; González, D.G. Hypofractionation in glioblastoma multiforme. Radiother. Oncol. 2000, 54, 143-148. [CrossRef]

21. Minniti, G.; De Sanctis, V.; Muni, R.; Rasio, D.; Lanzetta, G.; Bozzao, A.; Osti, M.F.; Salvati, M.; Valeriani, M.; Cantore, G.P.; et al. Hypofractionated radiotherapy followed by adjuvant chemotherapy with temozolomide in elderly patients with glioblastoma. $J$. Neurooncol. 2009, 91, 95-100. [CrossRef] [PubMed]

22. Thomas, R.; James, N.; Guerrero, D.; Ashley, S.; Gregor, A.; Brada, M. Hypofractionated radiotherapy as palliative treatment in poor prognosis patients with high grade glioma. Radiother. Oncol. 1994, 33, 113-116. [CrossRef]

23. Minniti, G.; Scaringi, C.; Lanzetta, G.; Terrenato, I.; Esposito, V.; Arcella, A.; Pace, A.; Giangaspero, F.; Bozzao, A.; Enrici, R.M. Standard (60 Gy) or short-course (40 Gy) irradiation plus concomitant and adjuvant temozolomide for elderly patients with glioblastoma: A propensity-matched analysis. Int. J. Radiat. Oncol. Biol. Phys. 2015, 91, 109-115. [CrossRef]

24. Pedretti, S.; Masini, L.; Turco, E.; Triggiani, L.; Krengli, M.; Meduri, B.; Pirtoli, L.; Borghetti, P.; Pegurri, L.; Riva, N.; et al. Hypofractionated radiation therapy versus chemotherapy with temozolomide in patients affected by RPA class V and VI glioblastoma: A randomized phase II trial. J. Neurooncol. 2019, 143, 447-455. [CrossRef] [PubMed]

25. Zhong, L.; Chen, L.; Lv, S.; Li, Q.; Chen, G.; Luo, W.; Zhou, P.; Li, G. Efficacy of moderately hypofractionated simultaneous integrated boost intensity-modulated radiotherapy combined with temozolomide for the postoperative treatment of glioblastoma multiforme: A single-institution experience. Radiat Oncol. 2019, 14, 104. [CrossRef]

26. Omuro, A.; Beal, K.; Gutin, P.; Karimi, S.; Correa, D.D.; Kaley, T.J.; DeAngelis, L.M.; Chan, T.A.; Gavrilovic, I.T.; Nolan, C.; et al. Phase II study of bevacizumab, temozolomide, and hypofractionated stereotactic radiotherapy for newly diagnosed glioblastoma. Clin. Cancer Res. 2014, 20, 5023-5031. [CrossRef] 
27. Bauman, S.; Gaspar, L.E.; Fisher, B.F.; Halperin, E.C.; Macdonald, D.R.; Cairncross, J.G. A prospective study of short-course radiotherapy in poor prognosis glioblastoma multiforme. Int. J. Radiat. Oncol. Biol. Phys. 1994, 29, 835-839. [CrossRef]

28. Curran, W.J., Jr.; Scott, C.B.; Horton, J.; Nelson, J.S.; Weinstein, A.S.; Fischbach, A.J.; Chang, C.H.; Rotman, M.; Asbell, S.O.; Krisch, R.E.; et al. Recursive partitioning analysis of prognostic factors in three Radiation Therapy Oncology Group malignant glioma trials. J. Natl. Cancer Inst. 1993, 85, 704-710. [CrossRef] [PubMed]

29. Therasse, P.; Arbuck, S.G.; Eisenhauer, E.A.; Wanders, J.; Kaplan, R.S.; Rubinstein, L.; Verweij, J.; Van Glabbeke, M.; van Oosterom, A.T.; Christian, M.C.; et al. New guidelines to evaluate the response to treatment in solid tumors. European Organization for Research and Treatment of Cancer, National Cancer Institute of the United States, National Cancer Institute of Canada. J. Natl. Cancer Inst. 2000, 92, 205-216. [CrossRef]

30. Fokas, E.; Wacker, U.; Gross, M.W.; Henzel, M.; Encheva, E.; Engenhart-Cabillic, R. Hypofractionated stereotactic reirradiation of recurrent glioblastomas: A beneficial treatment option after high-dose radiotherapy? Strahlenther Onkol. 2009, 185, 235-240. [CrossRef]

31. Navarria, P.; Minniti, G.; Clerici, E.; Tomatis, S.; Pinzi, V.; Ciammella, P.; Galaverni, M.; Amelio, D.; Scartoni, D.; Scoccianti, S.; et al. Re-irradiation for recurrent glioma: Outcome evaluation, toxicity and prognostic factors assessment. A multicenter study of the Radiation Oncology Italian Association (AIRO). J. Neurooncol. 2019, 142, 59-67. [CrossRef] [PubMed]

32. Lombardi, G.; De Salvo, G.L.; Brandes, A.A.; Eoli, M.; Rudà, R.; Faedi, M.; Lolli, I.; Pace, A.; Daniele, B.; Pasqualetti, F.; et al. Regorafenib compared with lomustine in patients with relapsed glioblastoma (REGOMA): A multicentre, open-label, randomised, controlled, phase 2 trial. Lancet Oncol. 2019, 20, 110-119. [CrossRef]

33. Fiorentino, A.; Balducci, M.; De Bonis, P.; Chiesa, S.; De Filippo, L.; Mangiola, A.; De Rose, F.; Autorino, R.; Rinaldi, C.; Fersino, S.; et al. Can elderly patients with newly diagnosed glioblastoma be enrolled in radiochemotherapy trials? Am. J. Clin. Oncol. 2015, 38, 23-27. [CrossRef]

34. Balducci, M.; Fiorentino, A.; De Bonis, P.; Chiesa, S.; Manfrida, S.; D’Agostino, G.R.; Mantini, G.; Frascino, V.; Mattiucci, G.C.; De Bari, B.; et al. Impact of age and co-morbidities in patients with newly diagnosed glioblastoma: A pooled data analysis of three prospective mono-institutional phase II studies. Med. Oncol. 2012, 29, 3478-3483. [CrossRef] [PubMed]

35. Fiorentino, A.; Caivano, R.; Chiumento, C.; Cozzolino, M.; Clemente, S.; Pedicini, P.; Fusco, V. Comorbidity assessment and adjuvant radiochemotherapy in elderly affected by glioblastoma. Med. Oncol. 2012, 29, 3467-3471. [CrossRef] [PubMed] 